\title{
INTEGRATED AHP AND FUZZY-PROMETHEE ON BEST SELECTION PROCESS
}

\author{
Rina Widyasari ${ }^{1}$, Hendra Cipta ${ }^{1}$, Ismail Husein ${ }^{1}$ \\ Program Studi Matematika FST \\ Universitas Islam Negeri Sumatera Utara
}

Email: rina_widyasari@uinsu.ac.id,hendracipta@uinsu.ac.id,husein_ismail@uinsu.ac.id

\begin{abstract}
In best selection process such as best student, best employee, best destination, etc. need an effective method so it may have the best object in output. Criteria on each process consist of among qualitative variable and numeric variable. In fact, to make a decision we cant use our feeling but should use science method. In our research we offer integrated AHP (Analytical Hierarchical Process) and Fuzzy-Promethee to solve the selection process that has among categorical variable. The result show algorithm from integrated AHP and Fuzzy-Promethee.
\end{abstract}

\section{Keywords: AHP, Fuzzy-Promethee, Integrated, Selection}

Abstrak. Dalam proses seleksi terbaik seperti siswa terbaik, karyawan terbaik, tujuan terbaik, dll memerlukan metode yang efektif sehingga memiliki objek terbaik dalam output. Kriteria untuk konsistensi antara variabel kualitatif dan variabel numerik adalah konsistensi. Sebenarnya, untuk membuat keputusan kita tidak bisa menggunakan perasaan kita tetapi harus menggunakan metode sains. Dalam penelitian kami, penawaran terintegrasi AHP (Analytical Hierarchical Process) dan Fuzzy-Promethe untuk menyelesaikan proses seleksi yang memiliki antara variabel kategori. Hasilnya menunjukkan algoritma dari AHP dan Fuzzy-Promethee terintegrasi.

Keywords: AHP, Fuzzy-Promethee, Integrasi, Pemilihan

\section{PENDAHULUAN}

Proses pemilihan mahasiswa terbaik, karyawan terbaik, tujuan wisata terbaik, pemasok terbaik dan lainnya membutuhkan suatu metode yang tepat agar hasil keluaran setelah proses tersebut merupakan objek terbaik. Hal yang mendasari suatu objek dikatakan terbaik yakni harus memiliki kriteria preferensi paling tinggi dibandingkan objek lainnya. Namun, sering dijumpai bahwa tidak semua kriteria objek tersebut memiliki preferensi paling tinggi.

Kriteria-kriteria preferensi dalam penelitian ini merupakan sejumlah variabel yang terdiri dari variabel kategorik dan variabel numerik. Pada kehidupan nyata, kita dihadapkan oleh sejumlah besar variabel kategorik sehingga mempersulit pengambil keputusan. Pengambilan keputusan tidak dapat dilakukan atas dasar perasaan atau masalah pribadi melainkan harus diuji secara ilmiah agar memperoleh hasil yang tepat serta efisien.

Variabel-variabel kategorik dalam jumlah besar dan mempersulit pengambilan keputusan dapat diselesaikan melalui reduksi kriteria penting. Reduksi kriteria ini bertujuan untuk menemukan kriteria-kriteria utama dalam memilih objek terbaik. Selain itu, reduksi ini juga bertujuan untuk efisiensi waktu. Setelah diperoleh kriteria 
utama, baik data dalam bentuk variabel kategorik maupun numerik diinput dan melalui proses fuzifikasi.

Dalam perkembangannya, Sistem Pendukung Keputusan (SPK) yang digunakan dalam menetapkan urutan peringkat, pilihan dan deteksi berkaitan dengan keputusan alternatif parameter yang efisien memenuhi beberapa kondisi tertentu (Amponsah et. al, 2012) adalah metode Preference Ranking Organization Method For Enrichment Evaluation (Promethee). Promethee merupakan metode untuk menyelesaikan suatu kasus pengambilan keputusan yang termasuk dalam kategori MCDM (Multi-criteria Decision Making) dengan prinsip outranking. Peneliti menggunakan metode kombinasi Fuzzy dan Promethee. Sistem ini terbukti efektif mampu memberikan rekomendasi solusi terbaik.

Penelitian terdahulu, dalam Hutabarat (2003), Sistem Pendukung Keputusan Penentuan Siswa Penerima Beasiswa Menggunakan Metode Promethee (Studi Kasus: SMP Perguruan Kebangsaan Medan) oleh Dewi Safitri Hutabarat (2013) menyimpulkan bahwa SPK dengan metode Promethee mampu memberikan solusi tepat sasaran. Kemudian Ardianto (2014) menerapkan metode Fuzzy-Promethee pada sistem pendukung keputusan pemilihan media iklan (studi kasus: PT. SidoMuncul) yang menyimpulkan sistem pendukung keputusan ini dapat membantu mempermudah proses pemilihan media iklan dengan memberikan perangkingan alternatif media iklan dari yang terbaik dan diharapkan juga mampu meningkatkan kualitas penilaian karena menggunakan metode yang telah teruji sebelumnya. Dengan berhasilnya dibuat sistem pendukung keputusan ini, membuktikan bahwa metode Fuzzy-Promethee mampu diimplementasikan pada sistem dan mampu diterapkan pada kasus untuk memilih media iklan yang terbaik. Sedangkan dalam dunia perbankan penerapan metode promethee dalam menentukan prioritas pinjaman kredit KPR kepada nasabah debitur (studi kasus: Bank BRI Syariah cabang Sidoarjo) oleh Fahroni Hadi Prabowo (2011) menyimpulkan sistem pendukung keputusan pemilihan debittur ini mampu menghasilkan alternatif nasabah debitur terbaik sesuais dengan perhitungan metode Promethee.

Berdasarkan permasalahan yang telah dipaparkan, peneliti mengusulkan sebuah penelitian dengan mengembangkan metode AHP dan Fuzzy-Promethee dalam proses seleksi yang dapat digunakan dalam seleksi mahasiswa berprestasi, karyawan terbaik, tujuan wisata terbaik, dan lainnya. Metode AHP digunakan dalam memilih kriteriakriteria utama kemudian diintegrasi dengan metode Fuzzy-Promethee yang dipilih karena penggunaannya yang mudah diaplikasikan, sederhana, tepat dan cepat dalam proses perhitungannya. Metode Fuzzy-Promethee singkatan dari Preference Rangking Organization Method for Enrichment Evaluation adalah suatu metode kombinasi antara Fuzzy dan Promethee untuk penentuan urutan (prioritas) dalam analisis multikriteria dan dapat memberikan penilaian secara lebih akurat dan objektif. Cara kerjanya adalah dengan memberikan bobot nilai terlebih dahulu pada setiap kriteria penilaian menggunakan Fuzzy baru kemudian diproses hasilnya menggunakan Promethee. Metode Fuzzy-Promethee digunakan karena dapat memecahkan permasalahan bersifat multikriteria dengan kemampuannya dalam proses penetapan nilai kriteria yang mengandung ketidakpastian dengan memperkenalkan bilangan fuzzy dan pada akhirnya akan dilakukan perangkingan berdasarkan urutan prioritas sesuai dengan perhitungan metode Promethee (Goumas, 2000). 


\section{Sistem Pendukung Keputusan (SPK)}

Sistem pendukung keputusan merupakan kajian mengenai identifikasi dan pemilihan alternatif berdasarkan tingkat nilai preferensi yang menjadi acuan penilaian (Haris, 2000). Sistem Pendukung Keputusan melalui interaksi antara manusia dan komputer dirancang untuk membantu dalam membuat suatu keputusan bagi decision maker (pembuat keputusan) dengan tingkat keefektifitasan yang baik (Alter, 1980).

Bonczek et al, (1981) mendefinisikan sistem pendukung keputusan sebagai sistem berbasis komputer yang terdiri dari tiga komponen yang saling berinteraksi. Sistem bahasa (mekanisme untuk memberikan komunikasi antara pengguna dan komponen sistem pendukung keputusan lain), sistem pengetahuan (repositori pengetahuan yang menjadi domain masalah yang ada pada sistem pendukung keputusan entah sebagai data atau sebagai prosedure), dan sistem pemrosesan masalah (hubungan anatara dua komponen lainnya, terdiri dari satu atau lebih kapabilitas manipulasi masalah umum yang diperlukan untuk pengambilan keputusan).

Sistem pendukung keputusan dapat meningkatkan optimasi pada layanan logistik dan membantu dalam menghasilkan keputusan yang efektif (Zhi and Zhao, 2014), dalam penelitian lainnya mengenai penilaian keefektifitasan kinerja dengan penggunaan sistem pendukung keputusan (Tal, 2014) dan efektifitas prediksi keuangan (Michael and Constantin, 2014) memberikan hasil keputusan akhir yang maksimal.

\section{Proses Pengambilan Keputusan (SPK)}

Dalam proses Sistem Pendukung Keputusan (SPK) terdapat tahap-tahap yang harus dilakukan. Adapun tahap-tahap yang harus lakukan dalam proses pengambilan keputusan sabagai berikut (Tal, 2014):

1. Tahap pemahaman (Intelligence Phase)

Proses yang terjadi pada tahap ini adalah menemukan masalah klasifikasi masalah, penguraian masalah, dan kepemilikan masalah. Tahap ini merupakan proses penelusuran dan pendeteksian dari lingkup problematika serta proses pengenalan masalah. Data masukan diperoleh, diproses dan diuji dalam rangka mengidentifikasikan masalah.

2. Tahap Perancangan (Design Phase)

Tahap ini meliputi pembuatan, pengembangan, dan analisis hal-hal yang mungkin untuk dilakukan. Termasuk juga pemahaman masalah dan pengecekan solusi yang layak dan model dari masalahnya dirancang, dites, dan divalidasi.

Tugas-tugas yang ada pada tahap ini yaitu:

a. Komponen-komponen model

b. Struktur model

c. Seleksi prinsip-prinsip pemilihan (kriteria evaluasi)

d. Pengembangan (penyediaan) alternatif

e. Prediksi hasil

f. Pengukuran hasil

g. Skenario

3. Tahap Pemilihan (Choice Phase)

Ada dua tipe pendekatan pemilihan, yaitu:

a. Teknis analitis yaitu menggunakan perumusan matematis

b. Algoritma menguraikan proses langkah demi langkah

4. Implementasi (Implementation Phase) 
Tahap ini dilakukan penerapan terhadap rancangan sistem yang telah dibuat pada tahap perancangan serta pelaksanaan alternatif tindakan yang telah dipilih pada tahap pemilihan.

\section{Prinsip - prinsip Dasar Analytical Hierarchy Process (AHP)}

Analytic Hierarchy Process (AHP) yang dikembangkan oleh Thomas Saaty pada tahun 1970-an merupakan suatu metode dalam pemilihan alternatif-alternatif dengan melakukan penilaian komparatif berpasangan sederhana yang digunakan untuk mengembangkan prioritas-prioritas secara keseluruhan berdasarkan ranking.

AHP adalah prosedur yang berbasis matematis yang sangat baik dan sesuai untuk evaluasi atribut-atribut kualitatif. Atribut-atribut tersebut secara matematik dikuantitatif dalam satu set perbandingan berpasangan, yang kemudian digunakan untuk mengembangkan prioritas-prioritas secara keseluruhan untuk penyusunan alternatif-alternatif pada urutan ranking / prioritas.

Kelebihan AHP dibandingkan dengan metode yang lainnya karena adanya struktur yang berhirarki, sebagai konsekuensi dari kriteria yang dipilih, sampai kepada subsub kriteria yang paling mendetail. Memperhitungkan validitas sampai dengan batas toleransi inkonsistensi berbagai kriteria dan alternatif yang dipilih oleh para pengambil keputusan (Saaty, 1990).

Karena menggunakan input persepsi manusia, model ini dapat mengolah data yang bersifat kualitatif maupun kuantitatif. Jadi kompleksitas permasalahan yang ada di sekitar kita dapat didekati dengan baik oleh model AHP ini. Selain itu AHP mempunyai kemampuan untuk memecahkan masalah yang multi-objektif dan multikriteria yang didasarkan pada perbandingan preferensi dari setiap elemen dalam hierarki. Jadi model ini merupakan suatu model pengambilan keputusan yang komperehensif.

Ada beberapa prinsip yang harus dipahami dalam menyelesaikan persoalan dengan AHP, diantaranya adalah : decomposition, comparative judgement, synthesis of priority dan logical consistency (Sri Mulyono, 2007 : 220).

\section{Decomposition}

Setelah persoalan didefinisikan, maka perlu dilakukan decomposition yaitu memecah persoalan yang utuh menjadi unsur-unsurnya. Jika ingin mendapatkan hasil yang akurat, pemecahan juga dilakukan terhadap unsur-unsurnya sampai tidak mungkin dilakukan pemecahan lebih lanjut, sehingga didapatkan beberapa tingkatan dari persoalan tadi. Karena alasan ini, maka proses analisis ini dinamakan hirarki (hierarchy). Ada dua jenis hirarki yaitu lengkap dan tak lengkap. Dalam hirakri lengkap, semua elemen pada suatu tingkat memiliki semua elemen yang ada pada tingkat berikutnya. Jika tidak demikian, dinamakan hirarki tak lengkap.

\section{Comparative Judgement}

Prinsip ini berarti membuat penilaian tentang kepentingan relatif dua elemen pada suatu tingkat tertentu dalam kaitannya dengan tingkat diatasnya. Penilaian ini merupakan inti dari AHP, karena ia akan berpengaruh terhadap prioritas elemenelemen. Hasil dari penilaian ini akan tampak lebih baik bila disajikan dalam bentuk matriks yang dinamakan matriks pairwise comparison. Pertanyaan yang biasa diajukan dalam penyusunan skala kepentingan adalah :

a. Elemen mana yang lebih (penting/disukai/mungkin)?, dan b. Berapa kali lebih (penting/disukai/mungkin)? 
Agar diperoleh skala yang bermanfaat ketika membandingkan dua elemen, seseorang yang akan memberikan jawaban perlu pengertian menyeluruh tentang elemen-elemen yang dibandingkan dan relevansinya terhadap kriteria atau tujuan yang dipelajari. Dalam penyusunan skala kepentingan ini, digunakan acuan seperti pada tabel berikut:

Tabel 2.1 Skala prioritas dalam AHP

\begin{tabular}{|c|l|}
\hline $\begin{array}{c}\text { Nila } \\
\text { i }\end{array}$ & \multicolumn{1}{|c|}{ Tingkat Kepentingan (Preference) } \\
\hline 1 & Sama pentingnya (Equal Importance) \\
\hline 2 & Sama hingga Sedikit Lebih penting \\
\hline 3 & Sedikit Lebih penting (Slightly more \\
\hline 4 & Sedikit Lebih hingga Jelas lebih penting \\
\hline 5 & Jelas lebih penting (Materially more \\
\hline 6 & Jelas hingga Sangat jelas lebih penting \\
\hline 7 & Sangat jelas lebih penting (Significantly more \\
\hline 8 & Sangat jelas hingga Mutlak lebih penting \\
\hline 9 & Mutlak lebih penting (Absolutely more \\
\hline
\end{tabular}

Dalam penilaian kepentingan relatif dua elemen berlaku aksioma reciprocal artinya jika elemen i dinilai 3 kali lebih penting daripada j, maka elemen $\mathrm{j}$ harus sama dengan $1 / 3$ kali pentingnya dibanding elemen i. Disamping itu perbandingan dua elemen yang sama akan menghasilkan angka 1, artinya sama pentingnya.

\section{Synthesis of Priority}

Dari setiap pairwise comparison kemudian dicari eigen vectornya untuk mendapatkan local priority. Karena matriks pairwise comparison terdapat pada setiap tingkat, maka untuk mendapatkan global priority dilakukan sintesa diantara local priority. Prosedur melakukan sintesis berbeda menurut bentuk hirarki. Pengurutan elemen-elemen menurut kepentingan relatif melalui prosedur sintesa dinamakan priority setting.

\section{Logical Consistency}

Konsistensi memiliki dua makna. Pertama adalah bahwa objek-objek yang serupa dapat dikelompokkan sesuai dengan keseragaman dan relevansi. Kedua adalah menyangkut tingkat hubungan antara objek-objek yang didasarkan pada kriteria tertentu.

Jenis-Jenis Analytical Hierarchical Process (AHP)

1. Single-criteria

Pilih satu alternative dengan satu kriteria. Pengambilan keputusan yang melibatkan satu/lebih alternatif dengan satu kriteria.

2. Multi-criteria

Pengambilan keputusan yang melibatkan satu/lebih alternative dengan lebih dari satu kriteria. Pilih satu alternative dengan banyak kriteria.

\section{Prosedur Analytical Hierarchical Process (AHP)}

Pada dasarnya, langkah-langkah prosedur dalam metode AHP meliputi:

1. Mendefinisikan masalah dan menentukan solusi yang diinginkan, lalu menyusun hirarki dari permasalahan yang dihadapi. Penyusunan hirarki adalah dengan menetapkan tujuan yang merupakan sasaran sistem secara keseluruhan pada level teratas.

2. Menentukan prioritas elemen 
a. Langkah pertama dalam menentukan prioritas elemen adalah membuat perbandingan berpasangan sesuai dengan kriteria yang diberikan.

b. Matriks perbandingan berpasangan diisi menggunakan bilangan untuk mempresentasikan kepentingan relative dari suatu elemen terhadap elemen yang lain.

3. Mengukur konsistensi

Dalam pembuatan keputusan, penting untuk mengetahui seberapa baik konsistensi yang ada karena kita tidak menginginkan keputusan berdasarkan pertimbangan dengan konsistensi yang rendah.Hal-hal yang dilakukan dalam lanhkah ini adalah sebagai beikut:

a. Kalikan setiap nilai pada kolom pertama dengan prioritas relatif elemen pertama, nilai pada kolom kedua dengan prioritas relative elemen kedua dan seterusnya.

b. Jumlahkan setiap baris

c. Hasil dari penjumlahan baris dibagi dengan elemen prioritas relative yang bersangkutan

d. Jumlahkan hasil bagi di atas dengan banyaknya elemen yang ada, hasilnya disebut $\lambda$ maks.

4. Hitung Consistensi Index (CI) dengan rumus:

$n=$ banyaknya elemen

$$
C I=(\lambda \operatorname{maks}-n) / n
$$

5. Penilaian Kriteria dan Alternatif

\section{Metode Fuzzy-Promethee}

Metode Fuzzy-Promethee yang dikembangkan oleh J. Geldermann, dkk. (2000), dimana memperluas metode Promethee dengan mempertimbangkan input yang mengandung informasi ketidakpastian yang dimodelkan dengan bilangan fuzzy. Penggunaan bilangan fuzzy tidak hanya terdapat pada skor evaluasi alternatif terhadap suatu kriteria $\left(f_{j}\left(a_{i}\right)\right)$, tetapi juga pada skor evaluasi bobot tiap kriteria $\left(w_{j}\right)$.

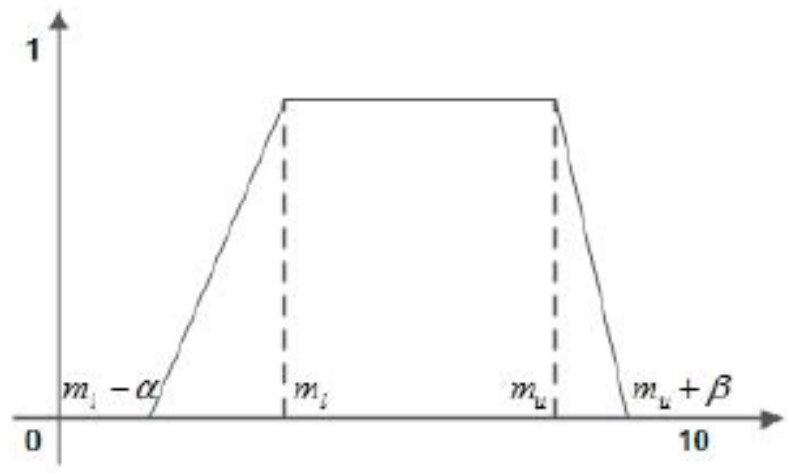

Gambar 1. Representasi Kurva FuzzyTrapesium Interval 
Fungsi keanggotaan untuk fuzzy trapesium interval secara matematika ditulis:

$$
\mu(x)=\left\{\begin{array}{cc}
0 & \text { untuk } x \leq m_{l}-\alpha \text { atau } m_{u}+\beta \leq x \\
1-\frac{m_{l}-x}{\alpha} & \text { untuk } m_{l}-\alpha<x<m_{l} \\
1 & \text { untuk } m_{l} \leq x \leq m_{u} \\
1-\frac{x-m_{u}}{\beta} & \text { untuk } m_{u}<x \leq m_{u}+\beta
\end{array}\right.
$$

Dimana $\alpha$ dan $\beta$ merupakan sebaran kiri dan sebaran kanan dari fuzzy trapesium interval, dan dengan interval $\left[m_{l}, m_{u}\right]$ dimana $m_{l}$ dan $m_{u}$ sebagai batas bawah dan batas atas dari angka yang mengandung kepastian dari beberapa set variabel yang ada. Fuzzy trapesium interval ini dinyatakan dengan notasi $M=\left(m_{l}, m_{u}, \alpha, \beta\right)_{L R}$. Bilangan segitiga fuzzy adalah kasus spesifik dari fuzzy trapesium interval dengan $m_{l}=m_{u}$ dan bilangan crisp $n$ dapat dirumuskan dengan $m_{l}=m_{u}=n$ dan $\alpha=\beta=0$. Operasi aljabarnya dinyatakan dengan:

Penjumlahan:

$$
\begin{aligned}
M^{\circ} \oplus N^{\circ} & =\left(m_{l}, m_{u}, \alpha, \beta\right)_{L R} \oplus\left(n_{l}, n_{u}, \gamma, \delta\right)_{L R} \\
& =\left(m_{l}+n_{l}, m_{u}+n_{u}, \alpha+\beta, \gamma+\delta\right)_{L R}
\end{aligned}
$$

Invers:

$$
-M^{O}=-\left(m_{l}, m_{u}, \alpha, \beta\right)_{L R}=\left(-m_{u},-m_{l}, \beta, \alpha\right)_{L R}
$$

Pengurangan:

$$
\begin{aligned}
M 0_{\mathrm{e}} N^{0} & =\left(m_{l}, m_{u}, \alpha, \beta\right)_{L R} \mathrm{e}\left(n_{l}, n_{u}, \gamma, \delta\right)_{L R} \\
& =\left(m_{l}-n_{l}, m_{u}-n_{u}, \alpha+\delta, \beta+\gamma\right)_{L R}
\end{aligned}
$$

Perkalian:

$$
\begin{aligned}
M 0 \otimes N O & =\left(m_{l}, m_{u}, \alpha, \beta\right)_{L R} \otimes\left(n_{l}, n_{u}, \gamma, \delta\right)_{L R} \\
& \approx\left(m_{l} \cdot n_{l}, m_{u} \cdot n_{u}, m_{l} \beta+n_{l} \alpha-\alpha \gamma, m_{u} \delta+n_{u} \beta+\beta \delta\right)_{L R}
\end{aligned}
$$

\section{RESULTS AND DISCUSSION}

\section{Integrasi metode AHP (Analytical Hierarchical Process) dan Fuzzy-Promethee}

Pemilihan objek terbaik tidak dapat dilakukan dengan menggunakan perasaan, hubungan kekerabatan ataupun ras. Predikat objek terbaik harus ditentukan menggunakan kriteria-kriteria preferensi yang datanya tidak hanya berbentuk data numerik namun juga data kategorik. Data tersebut dapat diperoleh dari kuesioner yang telah disebarkan kepada responden

Metode AHP adalah suatu metode yang dapat digunakan untuk menentukan kriteria yang paling baik digunakan untuk memilih objek terbaik. Setelah kriteriakriteria paling baik diperoleh, proses yang dilakukan selanjutnya adalah fuzifikasi data kualitatif, karena tidak semua data berbentuk numerik untuk diolah dengan metode Promethee.

\section{Algoritma Fuzzy-Promethee (F-Promethee)}


Penggandaan bilangan fuzzy dari tipe L-R yang sama tidak menghasilkan secara umum jenis fungsi referensi yang sama. Namun, jika penyebaran bilangan fuzzy trapesium adalah kecil cukup dibandingkan dengan batas bawah dan atas dari interval fuzzy, pendekatan (perkalian) dapat digunakan.

Dengan syarat-syarat ini, mungkin untuk mendesain ulang algoritma FuzzyPromethee (F-Promethee) yakni (J. Geldermann, 2000):

(F1) Tentukan untuk setiap kriteria $f_{k}$ merupakan fungsi preferensi umum $p_{k}(d)$

(F2) Tentukan vektor yang berisi bobot fuzzy (yang tidak perlu dinormalisasi ke $\left.\sum_{k=1}^{K} W_{k}=1\right):$

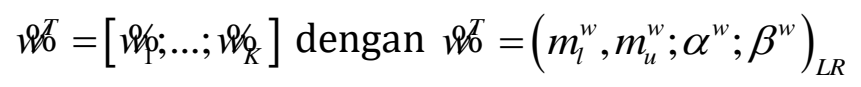

(F3) Tentukan semua alternatif $a_{t}, a_{t} \in A$ Fuzzy Outranking-Relation $f_{c}$ :

$$
\mathscr{A} 0\left\{\begin{array}{c}
A \times A \rightarrow[0,1] \\
\mathscr{A}\left(a_{t}, a_{t}\right)=\sum_{k=1}^{K} W_{k} \otimes p_{k}\left(f / o\left(a_{t}\right)-f / o\left(a_{i}\right)\right)
\end{array}\right.
$$

Dengan $f_{k}^{\prime o}\left(a_{t}\right)=\left(m_{l} ; m_{u} ; \alpha ; \beta\right)_{L R}$ dan $f_{k}^{\prime o}\left(a_{t}\right)=\left(n_{l} ; n_{u} ; \gamma ; \delta\right)_{L R}$, tingkat preferensi untuk perbandingan alternatif $a_{t}$ dan $a_{i}$ dengan kriteria $f_{k}$ dapat diturunkan (untuk perpanjangan preferensi dari bilangan real ke interval fuzzy, lihat gambar 9).

(F4) Sebagai ukuran untuk alternatif kekuatan $a_{t} \in A$, fuzzy leaving flow $\Phi^{+}\left(a_{t}\right)$ dihitung dengan:

$$
\Phi^{\circ}\left(a_{t}\right)=\frac{1}{T-1} \cdot \sum_{\substack{t=1 \\ t \neq 1}}^{T} \mathcal{A}\left(a_{t}, a_{t}\right)
$$

(F5) Sebagai ukuan alternatif kelemahan $a_{t} \in A$, fuzzy entering flow $\Phi^{-}\left(a_{t}\right)$ dihitung, dengan:

$$
\Phi^{\sigma}\left(a_{t}\right)=\frac{1}{T-1} \cdot \sum_{\substack{t=1 \\ t \neq 1}}^{T} \mathcal{T}\left(a_{t}, a_{t}\right)
$$

(F6) Sebuah evaluasi grafik dari hubungan outranking.

$$
\begin{aligned}
x_{\text {defuzz }}= & \frac{\int x \cdot \mu(x) d x}{\int \mu(x) d x} \\
= & \frac{\int_{m_{l-\alpha}}^{m_{l}}\left(1-\frac{m l-x}{\alpha}\right) \cdot x d x+\int_{m_{l-\alpha}}^{m_{u}} 1 \cdot x d x+\int_{m_{u}}^{m_{u+\beta}} \frac{x-m_{u}}{\beta} \cdot x d x}{\int_{m_{l-\alpha}}^{m_{l}}\left(1-\frac{m l-x}{\alpha}\right) d x+\int_{m_{l}}^{m_{u}} 1 \cdot x d x+\int_{m_{u}}^{m_{u+\beta}}\left(1-\frac{x-m_{u}}{\beta}\right) d x} \\
= & \frac{m_{u}^{2}-m_{l}^{2}+\alpha m_{l}+\beta m_{u}+\frac{1}{3}\left(\beta^{2}-\alpha^{2}\right)}{\alpha+\beta+2 m_{u}-2 m_{l}}
\end{aligned}
$$




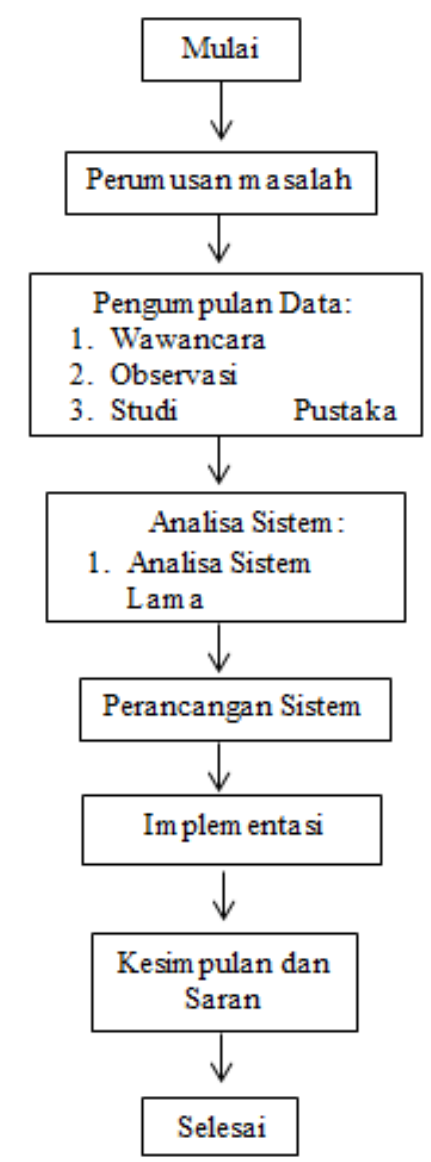

Gambar 2. Tahap-tahap Penelitian Metode Fuzzy-Promethee (Peneliti) Algoritma AHP-Fuzzy-Promethee

1. Mendefinisikan masalah dan menentukan solusi yang diinginkan lalu menyusun hirarki dari permasalahan yang dihadapi. Penyusunan hirarki adalah dengan menetapkan tujuan yang merupakan sasaran sistem secara keseluruhan pada level teratas.

2. Daftar semua variabel: variabel kategorik dan numerik

3. Menentukan prioritas elemen

a. Membuat perbandingan berpasangan sesuai dengan kriteria yang diberikan.

b. Matriks perbandingan berpasangan diisi menggunakan bilangan untuk mempresentasikan kepentingan relative dari suatu elemen terhadap elemen yang lain.

4. Mengukur konsistensi

Dalam pembuatan keputusan, penting untuk mengetahui seberapa baik konsistensi yang ada karena kita tidak menginginkan keputusan berdasarkan pertimbangan dengan konsistensi yang rendah.Hal-hal yang dilakukan dalam lanhkah ini adalah sebagai beikut:

a. Kalikan setiap nilai pada kolom pertama dengan prioritas relatif elemen pertama, nilai pada kolom kedua dengan prioritas relative elemen kedua dan seterusnya.

b. Jumlahkan setiap baris 
c. Hasil dari penjumlahan baris dibagi dengan elemen prioritas relative yang bersangkutan

d. Jumlahkan hasil bagi di atas dengan banyaknya elemen yang ada, hasilnya disebut $\lambda$ maks.

5. Hitung Consistensi Index (CI) dengan rumus:

$n=$ banyaknya elemen

$$
C I=(\lambda \operatorname{maks}-n) / n
$$

6. Penilaian Kriteria $\rightarrow$ Kriteria Utama

7. Kriteria-kriteria utama yang diperoleh dari metode AHP kemudian tentukan untuk setiap kriteria $f_{k}$ merupakan fungsi preferensi umum $p_{k}(d)$

8. Tentukan vektor yang berisi bobot fuzzy (yang tidak perlu dinormalisasi ke $\left.\sum_{k=1}^{K} w_{k}=1\right):$

$$
W_{\mathcal{O}}=\left[\mathscr{W}, \ldots ; \mathscr{W}_{K}\right]_{\text {dengan }} \mathscr{W}_{\mathcal{O}}=\left(m_{l}^{w}, m_{u}^{w} ; \alpha^{w} ; \beta^{w}\right)_{L R}
$$

9. Tentukan semua alternatif $a_{t}, a_{t} \in A$ Fuzzy Outranking-Relation $\mathscr{\theta}$ :

$$
f \circ\left\{\begin{array}{c}
A \times A \rightarrow[0,1] \\
f \phi\left(a_{t}, a_{i}\right)=\sum_{k=1}^{K} w_{k} \otimes p_{k}\left(f \circ\left(a_{t}\right)-f / o\left(a_{i}\right)\right)
\end{array}\right.
$$

10. Dengan $f_{k}^{f o}\left(a_{t}\right)=\left(m_{l} ; m_{u} ; \alpha ; \beta\right)_{L R}$ dan $f_{k}^{\circ}\left(a_{i}\right)=\left(n_{l} ; n_{u} ; \gamma ; \delta\right)_{L R}$, tingkat preferensi untuk perbandingan alternatif $a_{t}$ dan $a_{i}$ dengan kriteria $f_{k}$ dapat diturunkan

11. Alternatif kekuatan $a_{t} \in A$, fuzzy leaving flow $\Phi^{+}\left(a_{t}\right)$ dihitung dengan:

$$
\Phi^{\sigma}\left(a_{t}\right)=\frac{1}{T-1} \cdot \sum_{\substack{t=1 \\ t \neq 1}}^{T} \hat{t}\left(a_{t}, a_{t}\right)
$$

12. Alternatif kelemahan $a_{t} \in A$, fuzzy entering flow $\Phi^{-}\left(a_{t}\right)$ dihitung, dengan:

$$
\text { क大 }\left(a_{t}\right)=\frac{1}{T-1} \cdot \sum_{\substack{t=1 \\ i \neq 1}}^{T} \mathcal{T}\left(a_{t}, a_{t}\right)
$$

13. Hitung Net flow dengan cara Leaving Flow - Entering Flow

Hasil nilai fuzzy leaving flow dan fuzzy entering flow pada masing-masing alternatif. Semakin tinggi nilai leaving flow dan semakin rendah nilai entering flow semakin lebih baik alternatif tersebut. Namun demikian, hal ini bukan keputusan final, keputusan tetap berada di tangan pengambil keputusan.

\section{Kesimpulan dan Riset Lanjutan}

Penelitian ini mengajukan suatu metode baru dalam sistem seleksi yang mengandung banyak variabel kualitatif. Metode yang diajukan ialah mengintegrasikan metode Analytical Hierarchical Process yang menghasilkan kriteria-kriteria terbaik dalam proses pemilihan objek terbaik yang kemudian dilanjutkan menggunakan metode fuzzypromethee untuk memilih alternatif objek terbaik. 
Metode yang diajukan pada penelitian ini ialah integrasi metode AHP dengan fuzzy-promethee, metode berikutnya dalam menentukan alternatif terbaik dimana kriteria mengandung banyak variabel kualitatif dapat digunakan integrasi metode AHP dan Goal Programming atau Fuzzy-Promethee dengan Goal Programming.

\section{Acknowledgment}

Thanks to Prof. Dr. Herman Mawengkang that give advice and knowledgement to our research.

\section{REFERENCES}

[1] Alter, S.L., 1980, Decision Support Systems: Current Practice And Continuing Challenges, Reading, MA: Addison- Wesley.

[2] Amponsah, SK., Darkwah, KF and Inusah, A., 2012, Logistic Preference Function For Preference Ranking Organization Method For Enrichment Evaluation (Promethee) Decision Analysis, African Journal of Mathematics and Computer Science Research Vol. 5(6).

[3] Behzadian, M., Kazemzadeh R.B., Albadvi, A. and Aghasi, M. 2010. Promethee: $A$ Comprehensive Literature Review On Methologies And Applications.European Journal of Operational Research, 200, 198-215.

[4] Bonczek, R.H., Holsapple, C.W. and Whinston, A.B., 1981 Foundations of Decision Support Systems, New York: Academic Press

[5] Brans, J.P., B. Mareschal, dan Ph. Vincke (1986). How To Select And How To Rank Projects: The Promethee Method. European Journal of Operational Research, 24(2). 228-38. .

[6] Brans, J.P. dan B. Mareschal (2005). Promethee Methods. Multi-Criteria Decision Analysis: State of the Art Surveys. 163-89

[7] Cavallaro, F., 2005, An Integrated Multi-Criteria System to Assess Sustainable Energy Options: An. Application of the Promethee Method, Nota Di Lavoro, Milan: Fundazione Eni Enrico Mattei.

[8] Chen, Y.-H., Wang, T.-C., Wu, C.-Y. 2011. Strategic Decisions Using Fuzzy Promethee For Is Outsourcing. Expert Syst. Appl. 38, 12216-13222.

[9] Chou, TY., Lin, WT, Lin, CY., Chou, WC and Huang, PH., 2004, Application Of The Promethee Technique To Determine Depression Outlet Location And Flow Direction In DEM, Departments of Land Management, Feng-Chia University, Taiwan.

[10] Geldermann, J., T. Spengler, dan O. Rentz (2000). Fuzzy Outranking For Environmental Assessment. Case study: Iron And Steel Making Industry. Fuzzy Sets and System 115. 45-65.

[11] Goumas, M. dan V. Lygerou. 2000. An Extension Of The Promethee Method For Decision Making In Fuzzy Environment: Ranking Of Alternative Energy Exploitation Projects. European Journal of Operational Research 123. 606-13.

[12] Harris, R., 2000. Introduction to Decision Making, MA: Addison- Wesley.

[13] Hunjak, T., 1997, Mathematical Foundations Of The Methods For Multicriterial Decison Making, Mathematical Communications. 
[14] Kusumadewi, Sri. 2010. Aplikasi Logika Fuzzy Untuk Sistem Pendukung Keputusan (Edisi 2). Yogyakarta: Graha Ilmu.

[15] Mayasari, F, 2013. Sistem Pendukung Keputusan Pemilihan Calon Penerima Beasiswa PPA dan BBM Menggunakan Metode Fuzzy AHP, Smatika Jurnal, Vol. 3, No. 1.

[16] Michael D., Constantin Z., 2014, A Multicriteria Decision Support System For Bank Rating. International Journal on Soft Computing (IJSC), Vol.2, No. 1, February 2014.

[17] Sugiyono. 2009. Metode Penelitian Pendidikan Pendekatan Kuantitatif, Kualitatif, dan $R \& D$. Bandung : Alfabeta.

[18] Sukmadinata, Nana Syaodih. 2008. Metode Penelitian Pendidikan. Bandung: Remaja Rosdakarya.

[19] Sutopo. 2006. Metodologi Penelitian Kualitatif. Surakarta: UNS.

[20] Suryadi, K dan Ramdhani. (2002). Sistem Pendukung Keputusan : Suatu Wacana Struktural Idealisasi dan Implementasi Konsep Pengambilan Keputusan. Bandung : PT.Remaja Rosdakarya.

[21] Tal B. Z., 2014, Measuring the perceived effectiveness of decision support systems and their impact on performance. Procedia Soft Computing Sciences 111502-1506.

[22] Qu, S, Li, H., Guo, X., 2011, Application Of Interval-Promethee Method For Decision Making In Investing, ORSC \& APORC, pp. 314-321.

[23] Zhang, K., Kluck, C., and Achari, G. 2009. A Comparative Approach for Ranking Contaminated Sites Based on the Risk Assessment Paradigm Using FuzzyPromethee. Environment Management, 44,.952-967.

[24] Zhi H. H., Zhao H. S., 2014, A Decision Support System For Public Logistics Information Service Management And Optimization. Decision Support Systems with Applications 11-1502-1506 